COSTING:Journal of Economic, Business and Accounting

Volume 4 Nomor 2, Juni 2021

e-ISSN : 2597-5234

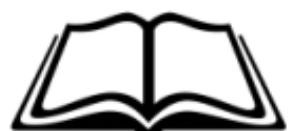

IMMEKpe

\title{
PENGARUH KEPERCAYAAN DAN PERSEPSI RISIKO TERHADAP KEPUTUSAN PEMBELIAN ONLINE SHOP TOKOPEDIA
}

\author{
THE EFFECT OF TRUST AND RISK PERCEPTION \\ ON TOKOPEDIA ONLINE SHOP PURCHASE DECISION
}

\author{
Fuji Puspa Sari' ${ }^{1}$ Hawignyo ${ }^{2}$ \\ Universitas Singaperbangsa Karawang, Indonesia ${ }^{1,2}$ \\ 1610631020157@student.unsika.ac.id ${ }^{1}$
}

\begin{abstract}
This study aims to determine the effect partially and simultaneously between Trust and Risk Perception on Online Shop Purchase Decisions of Tokopedia users in Karawang. This type of research is a quantitative research with descriptive and verification research methods. The population used in this study were users of the Tokopeia application in Karawang. The sample in this study amounted to 150 people using the Nonprobability Sampling technique. The test tool used in this research is SPSS version 25 software. The analysis model in this study uses a path analysis model. Based on the results of the study, it shows that there is a partial influence between Trust and Risk Perception of Online Shop Purchase Decisions of Tokopedia users in Karawang. The magnitude of the partial influence of Trust on Online Shop Purchase Decisions of Tokopedia users in Karawang is 17.2\%, while the effect of Risk Perception on Online Shop Purchase Decisions of Tokopedia users in Karawang is 42\%. Simultaneously, the effect of trust and risk perception on purchasing decisions based on the results of the study shows that the magnitude of the simultaneous influence is $59.2 \%$ and the remaining $40.8 \%$ is the influence of other variables not examined in this study.
\end{abstract}

Keywords: Trust, Perceived Risk, Purchasing Decisions

\begin{abstract}
ABSTRAK
Penelitian ini bertujuan untuk mengetahui pengaruh secara parsial maupun simultan antara Kepercayaan Dan Persepsi Risiko Terhadap Keputusan Pembelian Online Shop pengguna Tokopedia di Karawang. Jenis penelitian ini merupakan penelitian kuantitatif dengan metode penelitian deskriptif dan verivikatif. Populasi yang digunakan dalam penelitian ini adalah pengguna aplikasi Tokopeia di Karawang. Sampel dalam penelitian ini berjumlah 150 orang dengan menggunakan teknik Nonprobability Sampling. Alat pengujian yang digunakan dalam penelitian ini adalah software SPSS versi 25. Model analisis dalam penelitian ini menggunakan model analisis jalur. Berdasarkan hasil penelitian menunjukan bahwa terdapat pengaruh parsial antara Kepercayaan Dan Persepsi Risiko Terhadap Keputusan Pembelian Online Shop pengguna Tokopedia di Karawang. Besarnya pengaruh parsial Kepercayaan Terhadap Keputusan Pembelian Online Shop pengguna Tokopedia di Karawang adalah 17,2\%, sedangkan pengaruh Persepsi Risiko Terhadap Keputusan Pembelian Online Shop pengguna Tokopedia di Karawang sebesar 42\%. Secara simultan Pengaruh kepercayaan dan persepsi risiko terhadap keputusan pembelian berdasarkan hasil penelitian menunjukan bahwa besarnya pengaruh simultan sebesar $59,2 \%$ dan sisanya $40,8 \%$ merupakan pengaruh dari variabel lain yang tidak diteliti dalam penelitian ini.
\end{abstract}

Kata Kunci: Kepercayaan, Presepsi Risiko, Keputusan Pembelian 


\section{PENDAHULUAN}

Pada era globalisasi saat ini, perkembangan teknologi semakin maju dan berkembang pesat. Hampir setiap bidang kehidupan manusia dipengaruhi oleh teknologi yang membawa perubahan pada gaya hidup masyarakat yang lebih modern. Masyarakat menginginkan segalanya dapat terlaksana dengan cepat dan mudah atau yang biasa disebut dengan praktis. Teknologi saat ini sangat menguntungkan banyak orang dengan beragam manfaat yang diperoleh baik dalam bidang sosial maupun ekonomi. Salah satu perkembangan teknologi saat ini yakni hadirnya internet yang mampu mengubah ruang lingkup bisnis. (Sujana \& Suprapti, 2016).

Menurut statitika dilansir dalam databoks.katadata.co.id menyebutkan bahwa, Indonesia termasuk dalam 10 negara dengan pengguna internet terbesar di dunia. Dimana Indonesia menduduki peringkat kelima dengan pengguna internet sebanyak 143,26 juta per Maret 2019. Sedangkan untuk negara Brasil pengguna internetnya sebanyak 149,06 juta yang memiliki selisih tipis sebesar 5,8 juta dengan Indonesia. Hal ini mengindikasikan bahwa internet menjadi peran penting bagi manusia disegala aspek kehidupan. (qwords.com, 2019)

Seiring dengan peningkatan pengguna internet saat ini, internet mampu memberikan kemudahan dalam segala hal terutama bagi dunia bisnis yaitu perubahan perilaku masyarakat dalam berbelanja. Saat ini, belanja melalui online atau yang bisa disebut dengan online shopping menjadi pilihan masyarakat dimana, ketika ingin membeli barang atau jasa tidak perlu lagi keluar rumah dan mengantri untuk membayar guna memenuhi suatu kebutuhan. Hanya dengan menggunakan smartphone (ponsel) yang terhubung dengan koneksi internet sudah dapat melakukan transaksi jual beli dengan mudah. Belanja online (online shopping) merupakan suatu proses pembelian barang atau jasa melalui internet, atau layanan jual-beli secara online tanpa harus bertatap muka antara penjual atau pembeli secara langsung. Aktifitas jual beli online atau yang biasa dikenal dengan e-commerce dengan model marketplace merupakan paling banyak diminati oleh pengguna internet karena memiliki kelebihan keamanan tambahan dalam setiap transaksi. Menurut Jerry \& Peter (2014) e-commerce adalah proses dimana pembeli dan penjual melakukan pertukaran informasi, uang, dan barang melalui sarana internet.

Kepercayaan merupakan salah satu faktor penting dalam melakukan keputusan pembelian online. Dalam hal ini kepercayaan menjadi pondasi dalam bisnis apapun karena suatu transaksi bisnis antara dua belah pihak atau lebih akan terjadi apabila masing-masing pihak saling mempercayai. Dalam penelitian Mulyadi, et.al, (2018) mengatakan bahwa Kepercayaan adalah semua pengetahuan yang harus dimiliki konsumen terhadap suatu situs belanja online. Sehingga tanpa adanya kepercayaan tidak akan terjadinya transaksi dalam jual beli online.

$$
\text { Kotler \& Keller (2012) }
$$

menyatakan bahwa keputusan pembelian mencakup pilihan merek, pilihan penyalur, jumlah pembelian, waktu pembelian, dan cara pembelian. Dalam membuat suatu keputusan pembelian konsumen tidak terlepas dari beberapa faktor seperti: faktor kepercayaan, kemudahan, serta persepsi akan risiko yang dihadapi dalam keputusan pembelian.

Kepercayaan merupakan salah satu faktor penting dalam melakukan keputusan pembelian online. Dalam hal 
ini kepercayaan menjadi pondasi dalam bisnis apapun karena suatu transaksi bisnis antara dua belah pihak atau lebih akan terjadi apabila masing-masing pihak saling mempercayai (Mulyadi, et.al, 2018)

Faktor selanjutnya yaitu Perceived Risk (Persepsi Risiko) Zulfa \& Hidayati (2018) mendefinisikan bahwa persepsi risiko sebagai sebuah ketidakpastian yang dihadapi konsumen ketika mereka tidak dapat meramalkan konsekuensi di masa yang akan datang akibat keputusan pembelian yang dilakukan. Pada pembelian online, proses pembelian dan transaksi yang ada tidak terjadi secara langsung sehingga hanya dapat melihat barang melalui gambar dan tidak dapat menyentuhnya. Persepsi risiko juga menentukan seseorang dalam melakukan keputusan pembelian. Persepsi risiko yang semakin tinggi menyebabkan seseorang memiliki rasa takut saat bertransaksi secara online, begitu juga sebaliknya. Berbagai kekhawatiran dari transaksi e-commerce seperti: Takut tertipu, tidak memuaskan, kadang pengiriman yang lama dan sistem pemesanan yang membingungkan.

\section{METODE PENELITIAN}

Jenis penelitian ini merupakan penelitian kuantitatif dengan metode penelitian deskriptif dan verivikatif. Populasi yang digunakan dalam penelitian ini adalah pengguna aplikasi Tokopeia di Karawang. Sampel dalam penelitian ini berjumlah 150 orang dengan menggunakan teknik Nonprobability Sampling. Alat pengujian yang digunakan dalam penelitian ini adalah software SPSS versi 25. Model analisis dalam penelitian ini menggunakan model analisis jalur.

\section{HASIL DAN PEMBAHASAN Hasil Pengujian Keabsahan Data Uji Validitas}

Uji validitas merupakan suatu ukuran yang menunjukkan tingkat kevalidan suatu instrument dalam penelitian. Hasil analisis validitas menggunakan SPSS 21. Penulis dapat mengetahui bahwa kuesioner tersebut valid atau tidak valid dengan membandingkan nilai $r$, dimana nilai $r$ hitung $>\mathrm{r}$ tabel maka valid. Adapun hasil validitas pada variabel kepercayaan, presepsi risiko, dan keputusan pembelian sudah valid.

\section{Uji Reliabilitas}

Uji reliabilitas setiap variabel dalam penelitian ini menggunakan alat bantu SPSS 21. Pengujian relibilitas dilakukan untuk mengetahui reliabel atau tidaknya suatu instrumen atau item pernyataan. Adapun hasil dari uji reliabilitas variabel dalam penelitian ini adalah sebagai berikut:

Tabel 1Hasil Uji Reliabilitas

\begin{tabular}{llll}
\hline Variabel & r Hitung & r Tabel & Kriteria \\
\hline $\begin{array}{l}\text { Kepercayaan } \\
(\mathrm{X} 1)\end{array}$ & 0,864 & 0,6 & Relliabel \\
\hline $\begin{array}{l}\text { Persepsi } \\
\text { Risiko (X2) }\end{array}$ & 0,817 & 0,6 & Relliabel \\
\hline $\begin{array}{l}\text { Keputusan } \\
\text { pembelian } \\
(Y)\end{array}$ & 0,845 & 0,6 & Relliabel \\
\hline \begin{tabular}{l} 
Sumber: Hasil Pengolahan Data SPSS, (2020) \\
\hline
\end{tabular}
\end{tabular}

Berdasarkan Tabel 1 di atas, dapat diketahui bahwa variabel kepercayaan, persepsi risiko, dan keputusan pembelian memiliki nilai $\mathrm{r}>$ 0,6 yang artinya reliabel.

\section{Uji Normalitas}

Uji normalitas dilakukan untuk mengetahui apakah suatu data mengikuti sebaran normal atau tidak normal dengan menggunakan Kolmogorov-Smirnov yang dibantu oleh 
SPSS. Ketentuannya jika variabel memiliki $\alpha$ hitung lebih besar dari 0,05 maka variabel tersebut berdistribusi normal.

Tabel 2 Hasil Uji Normalitas

\begin{tabular}{llcl}
\hline \multirow{2}{*}{ Variabel } & \multicolumn{2}{l}{ Kolmogorof-Snirnov } & Kriteria \\
\cline { 2 - 3 } & r hitung & r kritis & \\
\hline $\begin{array}{l}\text { Kepercayaan } \\
\text { Persepsi }\end{array}$ & 0,704 & 0,05 & $\begin{array}{l}\text { Distribusi } \\
\text { Normal }\end{array}$ \\
$\begin{array}{l}\text { Risiko } \\
\text { Perceived }\end{array}$ & 0,534 & 0,05 & $\begin{array}{l}\text { Distribusi } \\
\text { Risk) }\end{array}$ \\
$\begin{array}{l}\text { Keputusan } \\
\text { pembelian }\end{array}$ & 0,511 & 0,05 & $\begin{array}{l}\text { Distribusi } \\
\text { Normal }\end{array}$ \\
\hline \multicolumn{3}{c}{ Sumber: Hasil Pengolahan Data SPSS, (2020) }
\end{tabular}

Berdasarkan

Tabel 2 menunjukkan hasil normalitas menggunakan Kolmogorov Smirnov, hasil pengolahan data menunjukkan nilai signifikan yang lebih besar dari 0,05. Maka dapat diketahui bahwa data tersebut berdistribusi normal.

\section{Analisis Deskriptif}

Variabel Kepercayaan

Berdasarkan hasil rekapitulasi tanggapan responden hasil penelitian mengenai variabel kepercayaan dapat dilihat pada tabel 3 .

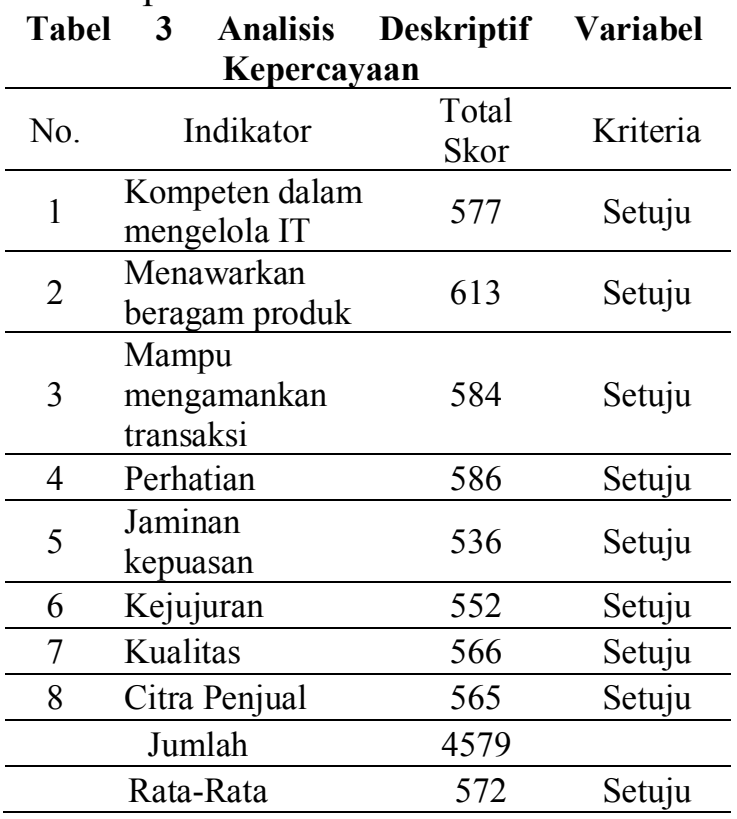

Sumber: Pengolahan Data, (2020)
Berdasarkan hasil penelitian diperoleh bahwa Kepercayaan pada pengguna Tokopedia yang memiliki 8 indikator dengan total skor 4.579 dan rata-rata skor sebesar 572,3 yang berada pada rentang 510-630 dengan kriteria setuju. Terdapat skor tertinggi yaitu pada indikator menawarkan beragam produk dan indikator Kompensasi Kerugian menjadi indikator yang memiliki skor terendah pada variabel Kepercayaan dengan skor 536.

Penyebab indikator menawarkan beragam produk memperoleh skor tertinggi dikarenakan pengguna Tokopedia percaya bahwa situs online Tokopedia menyediakan dan menawarkan berbagai produk dari berbagai brand. Sedangkan untuk indikator jaminan kepuasan memiliki skor terendah dikarenakan pengguna Tokopedia masih belum merasakan kepuasan saat berbelanja di Tokopedia.

\section{Variabel Presepsi Risiko}

Berdasarkan hasil rekapitulasi tanggapan responden hasil penelitian mengenai variabel presepsi risiko dapat dilihat pada tabel 4 .

\section{Tabel 4 Analisis Deskriptif Variabel Presepsi} Risiko

\begin{tabular}{|c|c|c|c|}
\hline No & Indikator & Total Skor & Kriteria \\
\hline 1 & Kerugian keuangan & 580 & Setuju \\
\hline 2 & $\begin{array}{l}\text { Dampak dari } \\
\text { lingkungan }\end{array}$ & 617 & Setuju \\
\hline 3 & $\begin{array}{l}\text { Ketidaksesuaian } \\
\text { produk }\end{array}$ & 611 & Setuju \\
\hline 4 & Rasa Kekecewaan & 613 & Setuju \\
\hline 5 & Waktu pengiriman & 602 & Setuju \\
\hline 6 & Penjaminan produk & 611 & Setuju \\
\hline 7 & $\begin{array}{l}\text { Kekhawatiran } \\
\text { produk }\end{array}$ & 600 & Setuju \\
\hline 8 & $\begin{array}{l}\text { Merasa tidak } \\
\text { nyaman }\end{array}$ & 559 & Setuju \\
\hline & Jumlah & 4793 & \\
\hline & Rata-Rata & 599 & Setuju \\
\hline
\end{tabular}


Berdasarkan hasil penelitian diperoleh bahwa Persepsi Risiko pada pengguna Tokopedia yang memiliki 8 indikator dengan total skor 4.793 dan rata-rata skor sebesar 599,1 yang berada pada rentang 510-630 dengan kriteria setuju. Terdapat skor tertinggi yaitu pada indikator kerugian keuangan dan indikator dampak dari lingkungan berpengaruh dalam pembelian menjadi indikator yang memiliki skor terendah pada variabel Persepsi Risiko (Perceived Risk) dengan skor 580.

Penyebab indikator kerugian keuangan berpengaruh dalam pembelian memperoleh nilai skor tertinggi dikarenakan pengguna Tokopedia mempertimbangkan terlebih dahulu kerugian keuangan yang dirasakan sebelum melakukan pembelian. Sedangkan, penyebab indikator dampak dari lingkungan memperoleh nilai skor terendah dikarenakan pengguna Tokopedia merasa kurangnya dampak yang dirasakan dari lingkungan sekitarnya.

\section{Variabel Keputusan Penggunaan}

Berdasarkan hasil rekapitulasi tanggapan responden hasil penelitian mengenai variabel presepsi risiko dapat dilihat pada tabel 5

Tabel 5 Analisis Deskriptif Variabel Keputusan Penggunaan

\begin{tabular}{clcc}
\hline No & \multicolumn{1}{c}{ Indikator } & $\begin{array}{l}\text { Total } \\
\text { Skor }\end{array}$ & Kriteria \\
\hline 1 & $\begin{array}{l}\text { Kebutuhan suatu } \\
\text { produk }\end{array}$ & 555 & Setuju \\
\hline 2 & $\begin{array}{l}\text { Keberagaman } \\
\text { varian produk }\end{array}$ & 559 & Setuju \\
\hline 3 & Kualitas produk & 541 & Setuju \\
\hline 4 & $\begin{array}{l}\text { ketertarikan pada } \\
\text { merek dan } \\
\text { popularitas merek }\end{array}$ & 544 & Setuju \\
\hline 5 & $\begin{array}{l}\text { Pelayanan yang } \\
\text { diberikan }\end{array}$ & 536 & Setuju \\
\hline 6 & $\begin{array}{l}\text { Ketersediaan } \\
\text { produk }\end{array}$ & 543 & Setuju \\
\hline 7 & $\begin{array}{l}\text { Keputusan jumlah } \\
\text { pembelian }\end{array}$ & 576 & Setuju \\
\hline
\end{tabular}

\begin{tabular}{clcc}
\hline 8 & $\begin{array}{l}\text { Membeli produk } \\
\text { dalam waktu } \\
\text { tertentu }\end{array}$ & 549 & Setuju \\
\hline 9 & $\begin{array}{l}\text { Cara pembayaran } \\
\text { yang dipakai }\end{array}$ & 575 & Setuju \\
\hline Jumlah & 4978 & \\
\hline Rata-Rata & 553,1 & Setuju \\
\hline
\end{tabular}

Sumber: Pengolahan Data, (2020)

Berdasarkan hasil penelitian diperoleh bahwa Persepsi Risiko pada pengguna Tokopedia yang memiliki 9 indikator dengan total skor 4.978 dan rata-rata skor sebesar 553,1 yang berada pada rentang 510-630 dengan kriteria setuju. Terdapat indikator yang memiliki skor terkecil yaitu pada indikator pelayanan yang diberikan. Sedangkan diketahui pula skor tertinggi berada pada indikator keputusan jumlah pembelian dengan skor 576 .

Penyebab indikator keputusan jumlah pembelian mendapatkan skor tertinggi dikarenakan pengguna Tokopedia merasa bebas menentukan jumlah barang yang ingin dibeli sesuai dengan kebutuhan yang dibutuhkan. Sedangkan untuk indikator pelayanan yang diberikan memiliki skor terendah dikarenakan pengguna Tokopedia merasa bahwa pihak Tokopedia kurang memberikan pelayanan baik dalam pengiriman barang ataupun dalam menangani keluhan.

\section{Analisis Verivikatif \\ Korelasi antara Kepercayaan dan Presepsi Risiko}

Dalam analisis jalur memiliki keterkaitan antara variabel bebas yang mempunyai korelasi, berarti dapat dihitung besaran pengaruh langsung maupun tidak langsung. Pengaruh tidak langsung merupakan perkalian antara koefisien jalur dengan koefisien korelasinya. Oleh karena itu terlebih dahulu dihitung masing-masing besaran koefisien korelasinya. korelasi antara 
kedua variabel bebas tersebut dapat dijelaskan pada Tabel 6 sebagai berikut:

Tabel 6 Korelasi Kepercayaan dan Presepsi Risiko

\begin{tabular}{llcr}
\hline & & $\begin{array}{c}\text { KEPERCA } \\
\text { YAAN }\end{array}$ & $\begin{array}{r}\text { PERSEPSI } \\
\text { RISIKO }\end{array}$ \\
\hline Kepercayaan & $\begin{array}{l}\text { Pearson } \\
\text { Correlation }\end{array}$ & 1 &, $542^{* *}$ \\
\cline { 2 - 4 } & $\begin{array}{l}\text { Sig. (2- } \\
\text { tailed) }\end{array}$ & &, 000 \\
\cline { 2 - 4 } & $\mathrm{N}$ & 150 & 150 \\
\hline $\begin{array}{l}\text { Persepsi } \\
\text { Risiko }\end{array}$ & $\begin{array}{l}\text { Pearson } \\
\text { Correlation }\end{array}$ &, $542^{* *}$ & 1 \\
\cline { 2 - 4 } & $\begin{array}{l}\text { Sig. (2- } \\
\text { tailed) }\end{array}$ &, 000 & \\
\cline { 2 - 4 } & $\mathrm{N}$ & 150 & 150 \\
\hline **. Correlation is significant at the 0.01 level (2- \\
tailed).
\end{tabular}

Sumber: Hasil Pengolahan Data SPSS, (2020)

Berdasarkan Tabel di atas menunjukkan nilai koefisien korelasi antara variabel bebas yaitu Kepercayaan dan Persepsi Risiko (Perceived Risk) adalah 0,542. Korelasi tersebut dapat dijelaskan dengan Gambar 1 di bawah ini:

\section{$\mathbf{0 , 5 4 2}$}

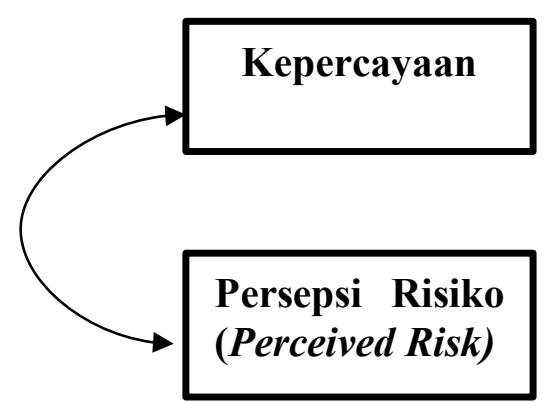

Gambar 1 Korelasi Antara Kepercayaan Dan Persepsi Risiko

Berdasarkan hasil penelitian menjelaskan bahwa terdapat hubungan antara Kepercayaan dan Persepsi Risiko (Perceived Risk). Hal ini dikarenakan memiliki nilai koefisien korelasi sebesar 0,542 atau sebesar $54,2 \%$ dan memiliki tingkat hubungan cukup kuat dan searah karena nilainya positif. Hasil penelitian ini sesuai dengan penelitian yang dilakukan oleh Rahmadi dan Malik
(2016) yang menyatakan bahwa variabel persepsi risiko (perceived risk) berpengaruh signifikan terhadap variabel kepercayaan. Riko (2015) dalam penelitiannya juga mengatakan bahwa persepsi risiko (perceived risk) berhubungan terhadap kepercayaan online. Menurut kimery dan McCard bahwa kepercayaan sebagai kesediaan konsumen untuk menerima kerentanan dalam melakukan transaksi online berdasarkan harapannya yang positif mengenai perilaku berbelanja online pada masa mendatang.

\section{Pengaruh Parsial Kepercayaan dan Persepsi Risiko Terhadap Keputusan Pembelian}

Berdasarkan hasil pengolahan data dengan menggunakan software SPSS 22, koefisien jalur untuk setiap variabel Kepercayaan dan Persepsi Risiko terhadap Keputusan Pembelian dapat dilihat pada tabel sebagai berilkut:

Tabel 7 Pengaruh Parsial Kepercayaan dan Persepsi Risiko Terhadap Keputusan Pembelian Standardi zed Unstandardized Coefficie Coefficients nts

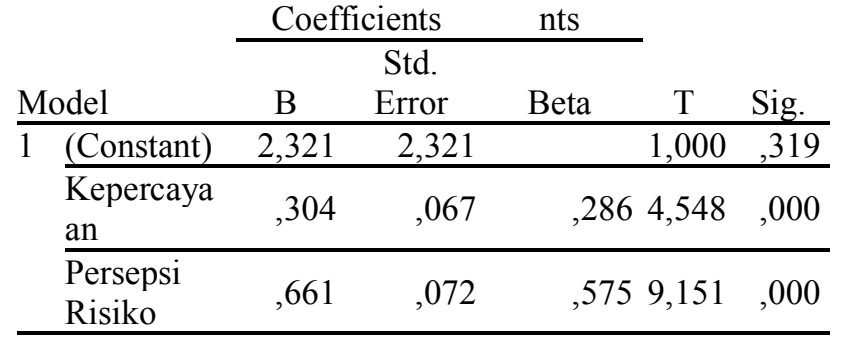

a. Dependent Variable: Keputusan pembelian

Sumber: Hasil Pengolahan Data SPSS, (2020)

Pengaruh langsung variabel Kepercayaan (X1) dan Persepsi Risiko (Perceived Risk) (X2) terhadap Keputusan Pembelian (Y) dapat digambarkan sebagai berikut: 


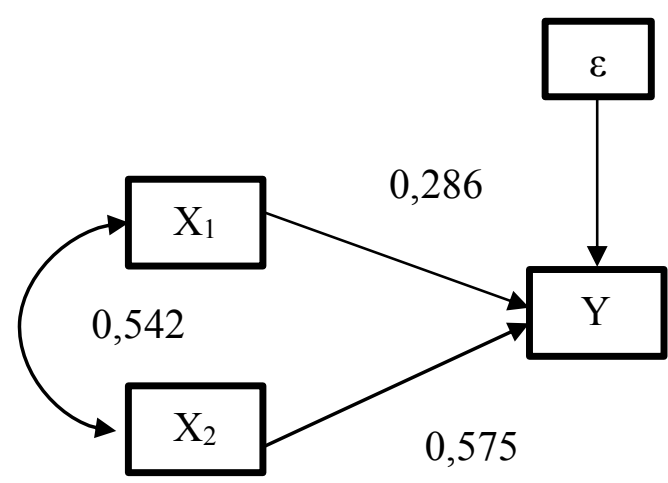

Gambar 2. Koefisien Jalur

Berdasarkan Gambar 2 menunjukkan bahwa nilai koefisien jalur variabel Kepercayaan $(0,286)$ lebih rendah dibandingkan niali koefisien jalur variabel Persepsi Risiko (Perceived Risiko) (0,575) artinya Persepsi Risiko (Perceived Risiko) lebih berpengaruh terhadap Keputusan Pembelian dibanding variabel Kepercayaan.

Tabel 8.Perhitungan Analisis Jalur Pengaruh Kepercayaan dan Persepsi Risiko Terhadap keputusan pembelian

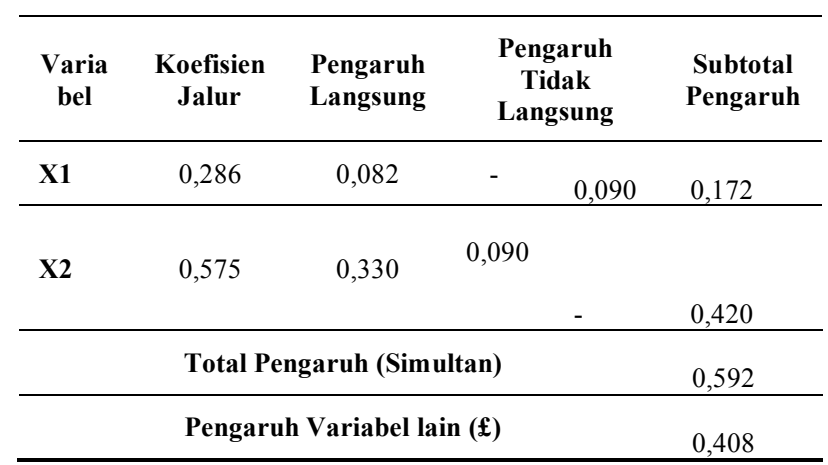

Sumber: Hasil Pengolahan Data SPSS, (2020)

Berdasarkan hasil penelitian pada tabel 8 menjelaskan bahwa terdapat pengaruh Kepercayaan terhadap Keputusan Pembelian yang memiliki nilai koefisien jalur 0,286 atau sebesar 28,6\%. Lalu pengaruh langsung Kepercayaan terhadap Keputusan Pembelian sebesar $8,2 \%$ serta pengaruh tidak langsung sebesar 9\%. Sehingga pengaruh parsial sebesar $17,2 \%$ dengan demikian Kepercayaan berpengaruh signifikan terhadap Keputusan Pembelian pada Tokopedia. Kepercayaan akan meningkatkan 17,2\% Keputusan Pembelian pada Tokopedia. Hasil penelitian ini sesuai dengan penelitian yang dilakukan oleh Riko (2015) bahwa kepercayaan berpengaruh positif signifikan terhadap Keputusan pembelian. Yurika, et.al (2019) menyatakan bahwa kepercayaan konsumen sebagai faktor penting dalam transaksi elektonik, dengan hasil penelitiannya bahwa Kepercayaan berpengaruh positif dan signifikan terhadap Keputusan pembelian.

Berdasarkan hasil penelitian menjelaskan bahwa terdapat pengaruh Persepsi Risiko (Perceived Risk) Keputusan Pembelian yang memiliki nilai koefisien jalur 0,575 atau sebesar $57,5 \%$. Lalu pengaruh langsung Persepsi Risiko (Perceived Risk) terhadap Keputusan Pembelian sebesar $33 \%$ serta pengaruh tidak langsung sebesar 9\%. Sehingga pengaruh parsial sebesar 42\%, dengan demikian Persepsi Risiko (Perceived Risk) berpengaruh signifikan terhadap Keputusan Pembelian pada Tokopedia. Persepsi Risiko (Perceived Risk) akan meningkatkan $\quad 42 \% \quad$ Keputusan Pembelian pada Tokopedia. Hasil penelitian ini sesuai dengan penelitian yang dilakukan oleh Yunita, et.al (2019) bahwa Persepsi Risiko (Perceived Risk) berpengaruh signifikan dan positif terhadap Keputusan Pembelian pada Komunitas Bukalapak Ponogoro. Hal ini dibuktikan dengan nilai thitung sebesar $3,666>t_{\text {tabel }} 1,998$ dengan nilai signifikansi sebesar 0,002.

Berdasarkan hasil penelitian pada tabel 8 diketahui bahwa pengaruh Persepsi Risiko (Perceived Risk) lebih besar daripada Kepercayaan terhadap Keputusan Pembelian Tokopedia, hal ini dikarenakan Persepsi Risiko 
(Perceived Risk) menjadi salah satu faktor penentu keberhasilan selama proses transaksi dalam situs Tokopedia.

Berdasarkan hasil penelitian pada tabel 8 menjelaskan bahwa terdapat Pengaruh antara Kepercayaan dan Persepsi Risiko (Perceived Risk) Terhadap keputusan Pembelian sebesar $59,2 \%$ dan sisanya sebesar 40,8\% dipengaruhi oleh faktor lain yang tidak diteliti. Hasil penelitian ini sesuai dengan penelitian yang dilakukan oleh (Rahmadi \& Malik, 2016) menyatakan bahwa terdapat pengaruh positif Kepercayaan dan Persepsi Risiko (Perceived Risk) terdadap Keputusan Pembelian E-Commerce pada Tokopedia.com di Jakarta Pusat sebesar $14,1 \%$. Selanjutnya melalui uji $\mathrm{f}$ menghasilkan bahwa Kepercayaan dan persepsi Risiko (Perceived Risk) berpengaruh secara simultan terhadap Keputusan Pembelian E-Commerce Tokopedia.com di Jakarta Pusat.

\section{PENUTUP \\ Kesimpulan}

Berdasarkan hasil dan pembahasan dalam penelitian ini, dapat ditarik kesimpulan yaitu sebagai berikut:

1. Korelasi antara kepercayaan dan persepsi risiko (perceived risk) pada situs belanja online Tokopedia diperoleh nilai koefisien sebesar $0,542 \%$ artinya hubungan antara kepercayaan dan persepsi risiko (perceived risk) mempunyai hubungan yang cukup kuat karena berada pada interval koefisien 0,40 $-0,599$.

2. Pengaruh kepercayaan terhadap keputusan pembelian sebesar $17,2 \%$ sedangkan pengaruh persepsi risiko terhadap keputusan pembelian sebesar42\%. Dengan demikian persepsi risiko berpengaruh lebih besar daripada kepercayaan terhadap keputusan pembelian pada Tokopedia, hal ini dikarenakan persepsi risiko menjadi salah satu faktor penentu keberhasilan selama proses transaksi dalam situs Tokopedia.

3. Pengaruh kepercayaan dan persepsi risiko terhadap keputusan pembelian berdasarkan hasil penelitian menunjukan bahwa besarnya pengaruh simultan sebesar $59,2 \%$ dan sisanya $40,8 \%$ merupakan pengaruh dari variabel lain yang tidak diteliti dalam penelitian ini. Dengan demikian kepercayaan dan persepsi risiko secara bersama-sama berpengaruh cukup kuat terhadap keputusan pembelian.

\section{Saran}

Hasil penelitian ini diharapkan mampu membantu peneliti selanjutnya untuk dijadikan acuan pada penelitiannya. Mengingat Kepercayaan dan Persepsi Risiko (PerceivedRisk) merupakaan variabel yang diteliti dalam penelitian ini dan menjadi salah satu faktor yang dapat mempengaruhi keputusan pembelian, maka untuk peneliti selanjutnya bisa mempertimbangkan kedua variabel tersebut sebagai faktor penting dalam meningkatkan keputusan pembelian. Selain itu, disarankan juga untuk peneliti selanjutnya menambahkan variabel lain e-service quality, persepsi keamanan dan lain-lain, dan juga bisa menggunakan alat analisis diluar dari SPSS.

\section{DAFTAR PUSTAKA}

Jerry C. O., \& Peter, J. P. (2014). Perilaku Konsumen dan Strategi Pemasaran. Edisi Sembilan. Salemba Empat: Jakarta.

Kotler, K. (2012). Manajemen Pemasaran. Edisi 12. Jakarta: Erlangga. 
Mulyadi, A., Eka, D., \& Nailis, W. (2018). Pengaruh Kepercayaan, Kemudahan, Dan Kualitas Informasi Terhadap Keputusan Pembelian di Toko Online Lazada. Jembatan, 15(2), 87-94. qwords.com, 2019 (diakses pada 28 Februari 2020 pukul 16.25 WIB) Rahmadi, H., \& Malik, D. (2016). Pengaruh Kepercayaan dan Persepsi Risiko terhadap Keputusan Pembelian ECommerce pada Tokopedia.Com di Jakarta Pusat. Reformasi Administrasi, 3(1), 126-145.

Riko A, Widayanto, M. S. (2019). Pengaruh Kepercayaan dan Risiko terhadap Keputusan Pembelian Melalui Sikap Pengguna pada Situs Belanja Online Lazada.Com. Journal of Chemical Information and Modeling, 53(9), 1689-1699.

Sujana, K., \& Suprapti, N. (2016). Peran Kepercayaan Dalam Memediasi Pengaruh Kualitas Situs Terhadap Niat Konsumen Untuk Berbelanja di Situs Zalora. E-Jurnal Manajemen Universitas Udayana, 5(1), 595622.

Yunita, N. R., Sumarsono, H., \& Farida, U. (2019). Pengaruh Persepsi Risiko, Kepercayaan, dan Keamanan Terhadap Keputusan Pembelian Online di Buka Lapak (Studi Kasus Pada Komunitas Buka Lapak Ponorogo). ISOQUANT: Jurnal Ekonomi, Manajemen dan Akuntansi, 3(1), 90-105.
Zulfa, L., \& Hidayati, R. (2018). Analisis Pengaruh Persepsi Risiko, Kualitas Situs Web, dan Kepercayaan Konsumen terhadap Keputusan Pembelian Konsumen E-commerce Shopee di Kota Semarang. Diponegoro Journal of Management, 7(3), 111. 